\title{
Population structure and individual movement of southern right whales around New Zealand and Australia
}

\author{
E. Carroll ${ }^{1, *}$, N. Patenaude ${ }^{2}$, A. Alexander ${ }^{1,3}$, D. Steel $^{3}$, R. Harcourt ${ }^{4}$, \\ S. Childerhouse ${ }^{5}$, S. Smith ${ }^{6}$, J. Bannister ${ }^{7}$, R. Constantine ${ }^{1}$, C. Scott Baker ${ }^{1,3}$ \\ ${ }^{1}$ Laboratory of Molecular Ecology and Evolution, School of Biological Sciences, University of Auckland, Auckland 1010, \\ New Zealand \\ ${ }^{2}$ LGL Limited, Environmental Research Associates, King City, Ontario L7B 1A6, Canada \\ ${ }^{3}$ Marine Mammal Institute and Department of Fisheries and Wildlife, Hatfield Marine Science Center, \\ Oregon State University, Newport, Oregon 97365, USA \\ ${ }^{4}$ Marine Mammal Research Group, Graduate School of the Environment, Macquarie University, Sydney, \\ New South Wales 2109, Australia \\ ${ }^{5}$ Australian Marine Mammal Centre, Australian Antarctic Division, DSEWPC, Kingston, Tasmania 7050, Australia \\ ${ }^{6}$ New Zealand Department of Conservation, Aquatic and Threats Unit, Wellington 6143, New Zealand \\ ${ }^{7}$ Western Australian Museum, Locked Bag 49, Welshpool DC, Western Australia 6986, Australia
}

\begin{abstract}
During the last 2 centuries, southern right whales Eubalaena australis were hunted to near extinction, and an estimated 150000 were killed by pre-industrial whaling in the 19th century and illegal Soviet whaling in the 20th century. Here we focus on the coastal calving grounds of Australia and New Zealand (NZ), where previous work suggests 2 genetically distinct stocks of southern right whales are recovering. Historical migration patterns and spatially variable patterns of recovery suggest each of these stocks are subdivided into 2 stocks: (1) NZ, comprising NZ subantarctic (NZSA) and mainland NZ (MNZ) stocks; and (2) Australia, comprising southwest and southeast stocks. We expand upon previous work to investigate population subdivision by analysing over 1000 samples collected at 6 locations across NZ and Australia, although sample sizes were small from some locations. Mitochondrial DNA (mtDNA) control region haplotypes (500 bp) and microsatellite genotypes (13 loci) were used to identify 707 individual whales and to test for genetic differentiation. For the first time, we documented the movement of 7 individual whales between the NZSA and MNZ based on the matching of multilocus genotypes. Given the current and historical evidence, we hypothesise that individuals from the NZ subantarctic are slowly recolonising MNZ, where a former calving ground was extirpated. We also suggest that southeast Australian right whales represent a remnant stock, distinct from the southwest Australian stock, based on significant differentiation in mtDNA haplotype frequencies $\left(F_{\mathrm{ST}}=0.15, \mathrm{p}<0.01 ; \Phi_{\mathrm{ST}}=0.12, \mathrm{p}=0.02\right)$ and contrasting patterns of recovery. In comparison with significant differences in mtDNA haplotype frequencies found between the 3 proposed stocks (overall $F_{\mathrm{ST}}=0.07, \Phi_{\mathrm{ST}}=0.12, \mathrm{p}<0.001$ ), we found no significant differentiation in microsatellite loci (overall $F_{\mathrm{ST}}=0.004, G_{\mathrm{ST}}^{\prime}=0.019, \mathrm{p}=0.07$ ), suggesting ongoing or recent historical reproductive interchange.
\end{abstract}

KEY WORDS: Southern right whale $\cdot$ Eubalaena australis $\cdot \operatorname{mtDNA} \cdot$ Microsatellite $\cdot$ Population structure

Resale or republication not permitted without written consent of the publisher

\section{INTRODUCTION}

The first documented hunting of southern right whales Eubalaena australis in the western South Pacific Ocean was in southeast Australia in 1805, although official records do not begin until the 1820s or later in most locations (Dawbin 1986). Hunting peaked in New Zealand and Australia in the 1830s and 1840s, resulting in the commercial extinction of southern right whales within 2 decades (Bannister 1986, Dawbin 
1986). It is estimated that at least 25000 southern right whales were killed in New Zealand and southeast Australia between 1827 and 1930 (Dawbin 1986). Illegal Soviet whaling from 1951 to 1971 killed a further 300 southern right whales in the waters around New Zealand and Australia, in violation of international protection introduced in 1935 (Tormosov et al. 1998).

The historical patterns of distribution and seasonal migration of southern right whales around New Zealand and Australia are complex and not well understood. Historical records suggest there were 2 coastal whaling grounds in New Zealand: one around the North and South Islands of New Zealand (NZ) (hereafter referred to as mainland NZ, MNZ), and the other at the subantarctic Auckland and Campbell Islands (hereafter referred to as the NZ subantarctic, NZSA; see Fig. 1; IWC 2001). Analysis of historical texts and whaling ship logbooks indicates that southern right whales inhabited bays and inlets around MNZ during the austral winter (Bannister 1986, Dawbin 1986). MNZ was predominantly a winter calving ground as historical sources commented on the unsustainable nature of the hunt that targeted cows with young calves (e.g. Sherrin 1886). In the NZSA whaling ground, southern right whales arrived as early as February and it is unclear whether this habitat was historically a calving or feeding ground, or a combination of both (Richards 2002). Despite the differences in the timing of historical migrations to MNZ and NZSA, it is possible these 2 areas were linked by a large-scale, seasonal migration pattern that has been inferred from historical sources (Richards 2002).

At the onset of whaling, southern right whales, in particular cows with calves, were found across the southern coast of Australia during the austral winter (IWC 1986). There was no real discontinuity in distribution or catch records to suggest subdivision of calving grounds in this region (IWC 1986). Based on the timing of catches at shore whaling stations during the 19th century, Dawbin (1986) proposed that southern right whales undertook 2 distinct patterns of migration along the southern coast of Australia during the austral winter. The southern right whales that migrated north along the east coast of Tasmania moved in a northeasterly direction up the coast of Victoria and New South Wales, while those that migrated north along the west coast of Tasmania moved from east to west along the southern coast of South and Western Australia. The latter pattern is still extant, based on the movement of photo-identified southern right whales and has been termed the 'counter-clockwise' migratory pattern (Kemper et al. 1997, Burnell 2001). Southern right whales from New Zealand and Australia move from these coastal winter calving grounds to off-shore, higher latitude summer feeding grounds in the austral spring. These areas are poorly described, but are known to include an area south of Western Australia (114 to $123^{\circ} \mathrm{E}$ and at least $60^{\circ} \mathrm{S}$; Bannister et al. 1999). There is some evidence from the analyses of mitochondrial DNA (mtDNA) data that whales from distinct calving grounds intermix on these feeding grounds (Baker et al. 1999, Patenaude et al. 2007).

Southern right whales currently show a pattern of spatially variable recovery across New Zealand and Australia. No southern right whale was seen around MNZ for over 35 yr (1928 to 1963, Gaskin 1964), and as recently as 2003, it was estimated that there were less than a dozen reproductive females in this area (Patenaude 2003). In contrast, southern right whales are currently found in large numbers in the NZSA, which is now considered the primary calving ground of the species in New Zealand waters (Patenaude et al. 1998, Stewart \& Todd 2001). The NZSA population was estimated to number 936 whales (95\% CI, 740-1140) in 1998, based on a capture-recapture analysis of individually identified whales photographed during winter surveys from 1995 to 1998 (Patenaude 2002). Given this spatial variation in density, it remains uncertain whether the NZSA and MNZ calving areas represent 2 relatively isolated stocks with different histories of exploitation and recovery, or are a single stock with a poorly understood pattern of migratory habitat use. The 2-stock hypothesis is consistent with the apparent difference in recovery between the regions (Patenaude 2002,2003 ) and the differences in the timing of historical migratory arrivals at the different whaling grounds (Dawbin 1986, Richards 2002). In contrast, the onestock hypothesis is consistent with the proposed largescale migratory pattern. A third hypothesis, which proposes that the MNZ calving ground was extirpated and the region is being recolonised by a range expansion from the NZSA, is also plausible.

In Australia, the Western Australian and Head of the Bight (South Australia) calving grounds also show signs of recovery (Burnell 2001, Bannister 2009). There is a high degree of interchange between these grounds, as documented by photo-identification studies, and they are considered a single 'southwest Australian' population numbering approximately 3000 whales (Burnell 2001, 2008, Bannister 2009). In contrast, sightings in the southeast of Australia remain infrequent and the demography of this small population is not well understood (Kemper et al. 1997, Bannister 2009). The population was estimated to number 76 whales in 1993 and Warrnambool, Victoria, appears to be the only consistent calving area in southeast Australia (Kemper et al. 1997). Of the few sightings in New South Wales, one has been matched with photo-identification to this Victorian calving ground (Kemper et al. 1997). This differential recovery parallels the New Zealand situation, 
with abundance in southwest Australia conceivably being an order of magnitude greater than that in southeast Australia, and supports the hypothesis that these 2 areas contain distinct stocks (Kemper et al. 1997, Bannister 2009). Alternatively, there may be one stock across the southern coast of Australia with patchy distribution, consistent with the lack of population structure suggested by historical data (IWC 1986).

Here we address the current population structure of southern right whales on calving grounds across New Zealand and Australia using mtDNA control region haplotypes (500 bp) and microsatellite genotypes (13 loci). Previous genetic studies have shown evidence of population structure on calving grounds based on differences in mtDNA haplotype frequencies between southwest Australia, NZSA, Argentina and South Africa (overall $F_{\mathrm{ST}}=0.159$; Patenaude et al. 2007). Those authors attributed this genetic differentiation to maternal fidelity to calving grounds, a conclusion supported by behavioural data from long-term studies in South Africa, Argentina and southwest Australia (Best et al. 2001, 2005, Burnell 2001, Cooke et al. 2001, Patenaude et al. 2007).

We extend these previous analyses with more comprehensive geographic sampling, a larger sample size and longer mtDNA control region sequence to investigate the structuring of maternal lineages on a regional scale. We also present the first analysis of population subdivision using microsatellite loci in southern right whales and use microsatellite genotypes to document the movement of individual whales between calving grounds. In addition, we specifically address the following stock structure hypotheses based on historical and current descriptions of distribution and migration of whales: that MNZ and NZSA represent 2 distinct stocks and that the Australian coast is subdivided into southeastern and southwestern calving grounds.

\section{MATERIALS AND METHODS}

Biopsy sample collection, DNA extraction and sex identification. Skin biopsy samples were collected with a small, stainless steel, biopsy dart fired from a modified veterinary capture rifle (Krützen et al. 2002) or deployed from a crossbow (Lambertsen 1987). Around the NZSA calving ground, field surveys collected biopsies during the austral winters of 1995 to 1998 and 2006 to 2008 ( $\mathrm{n}=934$; Table 1, Fig. 1). Around MNZ, samples were collected opportunistically by New Zealand Department of Conservation staff between 2003 and 2009 (n = 61). Samples were also collected from Bremer Bay/Doubtful Island Bay, West Australia (WA) in 1995 ( $\mathrm{n}=17$, as described by

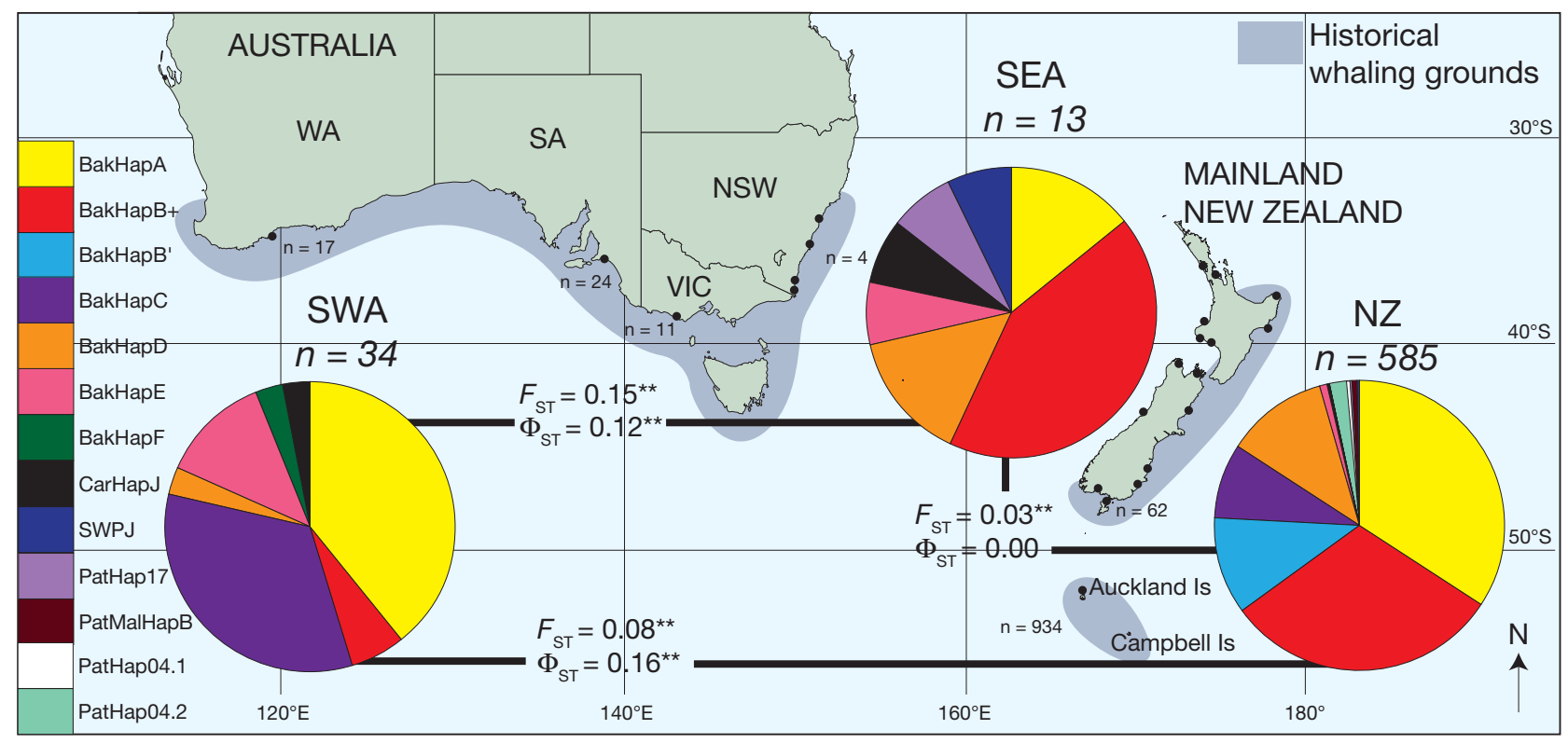

Fig. 1. Eubalaena australis. Mitochondrial (mtDNA) haplotype frequencies (500 bp) of southern right whale calving grounds across New Zealand (NZ) and Australia. Pairwise $F_{\mathrm{ST}}$ and $\Phi_{\mathrm{ST}}$ values are shown between the calving grounds; ${ }^{* *}$ represents significance $(p=0.05)$ after sequential Bonferroni correction. Small $n$ values refer to number of tissue samples collected from southern right whale calving grounds around NZ and Australia at the location indicated; $n$ values in italic text refer to the number of haplotypes in each sample associated with an individual, non-calf whale. The South Australia (SA) and Western Australia (WA) samples were pooled to form the southwest Australia (SWA) data set, Victoria (VIC) and New South Wales (NSW) samples were pooled to form the southeast Australia (SEA) data set and mainland NZ (North and South Islands) and NZ subantarctic (Auckland Islands) were pooled for the NZ data set 
Baker et al. 1999), and Cape Jervis/Encounter Bay, South Australia (SA, $\mathrm{n}=24$ ), Warrnambool, Victoria (VIC, $\mathrm{n}=11$ ) and along the coast of New South Wales (NSW), Australia $(n=4)$ between 2001 and 2009. Samples were stored in $70 \%$ ethanol in the field and transferred to $-20^{\circ} \mathrm{C}$ storage at the University of Auckland until further analyses. All sampling sites are considered to be calving grounds, except for SA, which is considered to be a migratory corridor.

Total genomic DNA was extracted from skin biopsy samples by means of standard Proteinase K digestion and phenol/chloroform methods (Sambrook et al. 1989) as modified by Baker et al. (1994) for small tissue samples. The sex of sampled whales was identified by amplification of the male-specific $S R Y$ gene, multiplexed with an amplification of the $Z F Y / Z F X$ region as positive control (Aasen \& Medrano 1990, Gilson et al. 1998).

Mitochondrial DNA control region haplotype sequencing and analyses. The mtDNA control region of all samples (approximately $950 \mathrm{bp}$ ) was amplified by PCR by means of standard protocols (Oremus et al. 2007) with the primers dlp1.5 (Baker et al. 1998) and tphe (ANN CAT TTT CAG TGY WTT GCT TT; C. S. Baker unpubl.), both modified with a 5'-M13

Table 1. Eubalaena australis. Number of tissue samples, microsatellite genotypes and mtDNA haplotypes collected from southern right whales on calving grounds and one migratory corridor (SA) around New Zealand (NZ) and Australia. The number of unique genotypes ( $\mathrm{N}$ genotypes) is the number of unique individuals after replicates and dependent calves of the year were removed. For testing of putative stocks, regions were pooled as follows: NZ subantarctic (NZSA) and mainland NZ (MNZ) were pooled for NZ; New South Wales (NSW) and Victoria (VIC) were pooled for southeast Australia (SEA); South Australia (SA; migratory corridor) and Western Australia (WA) were pooled for southwest Australia (SWA). The number of mtDNA haplotypes (N mtDNA) represents only those haplotypes associated with unique genotypes. Individuals identified as calves were excluded from some analyses. Sex was not identified for every sample

\begin{tabular}{|c|c|c|c|c|c|c|}
\hline \multirow{2}{*}{$\begin{array}{l}\text { Region or } \\
\text { stock }\end{array}$} & \multirow{2}{*}{$\begin{array}{c}\mathrm{N} \\
\text { samples }\end{array}$} & \multirow{2}{*}{$\begin{array}{c}\mathrm{N} \\
\text { calf }\end{array}$} & \multirow{2}{*}{$\begin{array}{l}\text { N geno- } \\
\text { types }\end{array}$} & \multirow{2}{*}{$\begin{array}{c}\mathrm{N} \\
\mathrm{mtDNA}\end{array}$} & \multicolumn{2}{|c|}{ Sex } \\
\hline & & & & & M & $\mathrm{F}$ \\
\hline NZSA & 934 & 46 & 571 & $551^{\mathrm{a}}$ & 264 & 291 \\
\hline MNZ & 61 & 4 & 39 & 39 & 17 & 22 \\
\hline All NZ (total) & ) 995 & 50 & $605^{\mathrm{b}}$ & $585^{\mathrm{b}}$ & 280 & 309 \\
\hline NSW & 4 & 0 & 4 & 4 & 0 & 4 \\
\hline VIC & 11 & 0 & 9 & 9 & 0 & 8 \\
\hline SEA (total) & 15 & 0 & 13 & 13 & 0 & 12 \\
\hline SA & 24 & 0 & 21 & 21 & 11 & 10 \\
\hline WA & 17 & 0 & 13 & $13^{\mathrm{c}}$ & 8 & 5 \\
\hline SWA (total) & 41 & 0 & 34 & 34 & 19 & 15 \\
\hline Total & 1051 & 50 & 657 & 637 & 299 & 336 \\
\hline \multicolumn{7}{|c|}{$\begin{array}{l}\text { a'Includes } 42 \text { samples used in Patenaude et al. }(2007) \\
{ }^{\mathrm{b}} \text { Five non-calf replicates were identified between NZSA } \\
\text { and MNZ and were removed for pooled analyses } \\
{ }^{\mathrm{c} S a m p l e s} \text { used in Patenaude et al. (2007) with replicate } \\
\text { samples removed }\end{array}$} \\
\hline
\end{tabular}

primer extension (5'-TGT AAA ACG ACA GCC AGT$\left.3^{\prime}\right)$ to facilitate subsequent sequencing reactions. PCR products were purified for sequencing with ExoSAP-IT (USB) and sequenced with BigDye ${ }^{\mathrm{TM}}$ Dye Terminator Chemistry (Applied Biosystems) on a genetic analyser (ABI 3730 or an ABI 3130, Applied Biosystems).

Sequences were aligned and edited in either of the programs, Sequencher v. $4.2^{\mathrm{TM}}$ (Gene Codes) or Geneious v. 2.5 (Drummond et al. 2006). Haplotypes were identified from a 275 bp consensus region with haplotype codes established by Patenaude et al. (2007), with revisions described in Tables $\mathrm{S} 1 \& \mathrm{~S} 2$ in the supplement at www.int-res.com/articles/suppl/m432p257_supp.pdf. Haplotype $(h)$ and nucleotide $(\pi)$ diversity were estimated using Arlequin v. 3.1 (Excoffier et al. 2005). Differentiation between sampling locations was estimated with pairwise $F$-statistics $\left(F_{\mathrm{ST}}\right), \Phi_{\mathrm{ST}}$ and an analysis of molecular variance (AMOVA; Wright 1949, Weir \& Cockerham 1984), calculated in Arlequin v. 3.1. The significance of these differences was tested with a permutation procedure in Arlequin v. 3.1 (10000 permutations, with significance set at $\alpha=0.05$ ). Given the small size of some of the samples, we also carried out comparisons using an exact test of differentiation (1 000000 Markov chain steps; 1000000 dememorization steps, with significance set at $\alpha=0.05$; Raymond \& Rousset 1995). Given the potential for Type II error when using the simple Bonferroni correction (Narum 2006), we report the p-values of these tests, with and without the sequential Bonferroni correction (Holm 1979, Rice 1989).

Microsatellite genotyping and analyses. Thirteen microsatellite loci were amplified in individual $10 \mu \mathrm{l}$ PCR reactions under conditions and reaction mixtures described in Table S3 in the Supplement (EV1, EV37 and EV14: Valsecchi \& Amos 1996; GATA28 and GATA98: Palsbøll et al. 1997; RW18, RW31, RW410 and RW48: Waldick et al. 1999; GT23: Bérubé et al. 2000; TR3G1, TR3G2 and TR3F4: Frasier et al. 2006). Each 96-well tray included a set of 7 standard samples as an internal control to ensure consistent allele sizing and a negative control to detect contamination. Amplicons from 4 to 6 loci were co-loaded for capillary electrophoresis with an ABI 3730 or an ABI 3130.

Alleles were sized with Genemapper v. 4.0 (Applied Biosystems) and all automated calling was confirmed visually (Bonin et al. 2004). We tested for linkage disequilibrium and deviations from the Hardy-Weinberg equilibrium with GENEPOP v. 4.0 (Raymond \& Rousset 1995). To detect large allele dropout, null alleles and evidence of stutter we used Micro-Checker (van Oosterhout et al. 2004). Observed and expected heterozygosities were calculated in CERVUS v. 3.0 (Kalinowski et al. 2007) and allelic richness was calculated with FSTAT (Goudet 2001). We used the program DROPOUT 
(McKelvey \& Schwartz 2005) to evaluate the number of matching loci required to identify replicate samples with confidence. The average probability of identity (PID; Paetkau \& Strobeck 1994) across the data set was calculated in GENALEX v. 6.0 (Peakall \& Smouse 2006) and matching genotypes were identified by CERVUS v. 3.0. When a replicate genotype was identified, only 1 copy of the genotype was retained per sampling location for subsequent analyses. The error rate was calculated per allele (Pompanon et al. 2005) with the internal control samples amplified in every PCR reaction.

Pairwise and overall $F_{\mathrm{ST}}$ values for microsatellite loci were calculated in GENEPOP v. 4.0 (Rousset 2008) and the exact $G$-test was used in the same program to test for significant differences in allele frequencies between sampling locations (Raymond \& Rousset 1995). The standardised index of differentiation or $G$-statistic

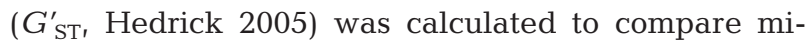
crosatellite allele frequencies between regions with GENODIVE v. 2.0b1 (Meirmans \& van Tienderen 2004) and GENEPOP v. 4.0 following Meirmans (2006). The sequential Bonferroni correction was included as described in the previous section.

Testing a priori hypotheses and sex-biased dispersal. Primary tests for population structure were based on a priori subdivisions from the stock structure hypotheses described in the 'Introduction'. Sampling locations within proposed stocks were tested for differentiation with pairwise comparisons of mtDNA $F_{\mathrm{ST}}$ and $\Phi_{\mathrm{ST}}$ and microsatellite $F_{\mathrm{ST}}$ and $G_{\mathrm{ST}}^{\prime}$ calculations. Based on the results of these tests, we pooled samples into stocks and repeated the tests of differentiation.

In addition, we tested for sex-bias in dispersal using the biased dispersal option in program FSTAT (Goudet et al. 2002). The most sensitive tests, differences in $F_{\mathrm{ST}}$ and variance of corrected assignment index (vAIc) between males and females, were tested by generating null distributions with 10000 permutations.

To test for population structure that might not conform to these a priori hypotheses, we used the program STRUCTURE v. 2.3 (Pritchard et al. 2000). The fit of the data to $K$ populations ( $K=1$ to 6 ) was assessed with the admixture and correlated allele frequency model, with 500000 burn-ins and 1000000 runs. The $\Delta \mathrm{K}$ method was used to estimate true K (Evanno et al. 2005).

\section{RESULTS}

\section{Individual identification and movement between regions}

Given some variation in the quality and quantity of DNA, not all samples were genotyped at all 13 loci, but a total of 939 samples were genotyped at between 9 and 13 loci (average, 11.8 loci). An initial review with the program DROPOUT showed that a minimum of 7 loci were sufficient to identify replicate samples, as the PID was sufficiently small to preclude matching genotypes by chance (PID $\leq 2.09 \mathrm{E}-08$ ). In practice, the replicate samples matched at an average of 11 loci, in addition to mtDNA haplotype and sex. The identification and removal of matching samples within each region resulted in a total sample of 707 unique individuals. This total included 50 dependent calves (see Table 1), which were included when identifying replicates between regions, but excluded from all other analyses. Sex was identified for 640 of the 657 non-calf whales. There was no significant deviation from a 1:1 sex ratio at any sampling location, with the exception of VIC (binomial test result, $\mathrm{p}=0.003$ ).

Comparison of microsatellite genotypes between sampling locations resulted in 7 matches (5 females and 2 males), all between the NZSA and MNZ data sets. These 7 replicate samples matched at all loci compared, and were supported by a PID $\leq 1.10 \mathrm{E}-12$ and identical mtDNA haplotypes and genetically identified sex (see Table S4 in the Supplement). These replicates (i.e. genotypic recaptures) were retained in both data sets for direct comparisons where appropriate. No between-sampling location matches were found in the Australian data set, or between NZ and Australia.

Of the 13 loci, 12 were in Hardy-Weinberg equilibrium (HWE) in all sampling locations. The exception was TR3G1, which deviated from HWE and showed evidence of null alleles in the NZSA calving ground but at no other sampling site, and so was retained. In addition, no pair of loci showed significant linkage disequilibrium. Internal control samples were successfully amplified 2152 times, including 14 single-allele errors, giving a per allele error rate of $0.65 \%$ (Pompanon et al. 2005). This is consistent with previously reported studies (Bonin et al. 2004).

\section{mtDNA diversity and differentiation}

Sequences of the mtDNA control region (500 bp consensus) were available for 637 of the 657 unique individuals after the removal of calves and replicate samples (Table 1). The 500 bp consensus sequence revealed 31 variable sites that defined 13 haplotypes (Table 2). The NZSA sample $(\mathrm{n}=551)$ included 11 haplotypes, compared with 4 found in previous analyses ( $\mathrm{n}=42$, Patenaude et al. 2007). All haplotypes were shared between at least 2 regions, with the exception of BakHapF, which was unique to WA, and PatMalHapB, unique to NZSA in this study. Diversity indices are reported for $500 \mathrm{bp}$, the sequence length used for 
analyses in this study, and at $275 \mathrm{bp}$ to facilitate comparison with previous studies (Table 3 ).

Significant differentiation in mtDNA haplotype frequencies was found among the sampling locations (overall $F_{\mathrm{ST}}=0.037, \mathrm{p}=0.002 ; \Phi_{\mathrm{ST}}=0.066, \mathrm{p}<0.001$; exact test result, $\mathrm{p}<0.001)$. The greatest differentiation was found when NZSA or MNZ were compared with SA or WA (Table 4). Furthermore, VIC was significantly different from WA based on mtDNA haplotype frequencies (Table 4).

\section{Microsatellite diversity and differentiation}

Microsatellite loci showed relatively high levels of observed heterozygosity $\left(H_{0}\right)$ and number of alleles $(k)$ per loci at all sampling locations (Table 5 ; for this information categorised by sampling site and stock see Table S5 in the Supplement). However, direct comparisons with other studies should be considered with caution as there is an ascertainment bias in this data set; the microsatellite loci used in this study were selected for the purposes of individual identification and as such were selected owing to high variability.

In contrast to the differentiation seen in mtDNA haplotype frequency data, there was no significant difference in microsatellite allele frequencies overall $\left(F_{\mathrm{ST}}=0.001\right.$, exact $G$-test, $\left.\mathrm{p}=0.19\right)$ or in most pairwise comparisons (Table 4). A significant pairwise difference was only found between the VIC and WA calving grounds (Table 4).

\section{Testing stock hypotheses and sex-biased dispersal}

Based on the pairwise comparisons of the MNZ and NZSA samples, we could discount the 2-stock hypothesis for NZ (Table 4). Accordingly, MNZ and NZ were pooled to form a single 'NZ' stock data set. SA and WA were pooled into a southwest Australian (SWA) data set as the comparison showed no significant differentiation in either mtDNA or microsatellite allele frequencies (Table 4). The NSW and VIC samples were pooled to form a southeast Australian data set (SEA). Unfortunately the NSW sample was very small, but it was combined with the VIC sample owing to the geographic proximity, photo-identification match between the 2 areas (Burnell 2001) and lack of differentiation in mtDNA $\left(F_{\mathrm{ST}}=0.00, \mathrm{p}=0.37 ; \Phi_{\mathrm{ST}}=\right.$ $0.00, \mathrm{p}=0.57$ ).

After pooling there was significant overall $\left(F_{\mathrm{ST}}=\right.$ $\left.0.07, \Phi_{\mathrm{ST}}=0.12, \mathrm{p}<0.001\right)$ and pairwise differentiation between all 3 putative stocks, based on mtDNA haplotype data (with the exception of the $\Phi_{\mathrm{ST}}$ between NZ and SEA; Table 4). In addition, a small but significant differentiation was found between NZ and SWA in the microsatellite allele frequency data (Table 4 ), but the overall value was non-significant (overall $F_{\mathrm{ST}}=0.004$, $G_{\text {ST }}^{\prime}=0.019, \mathrm{p}=0.069$ )

Analysis of microsatellite genotypes with the Bayesian clustering method in program STRUCTURE provided no evidence of cryptic population structure. Although the $\Delta \mathrm{K}$ method of Evanno et al. (2005) favoured $\mathrm{K}=2$ (Fig. 2), on closer inspection all individ-

Table 2. Eubalaena australis. Variable sites defining 13 haplotypes (GenBank accession numbers JN097593 to JN097605) in the 500 bp consensus region of mtDNA control region of southern right whales. The frequencies of haplotypes are shown for each of the 6 sampling regions across New Zealand (NZ) and Australia, including NZ subantarctic (NZSA), mainland NZ (MNZ), New South Wales (NSW), Victoria (VIC), South Australia (SA; migratory corridor) and Western Australia (WA). Position 1 corresponds to position 1 in Baker et al. (1999) and Patenaude et al. (2007) and shaded area shows variable sites used to define haplotypes in those studies. For region codes see Table 1 and for haplotype synonyms see supplementary material (www.int-res.com/articles/suppl/m432p257_supp.pdf)

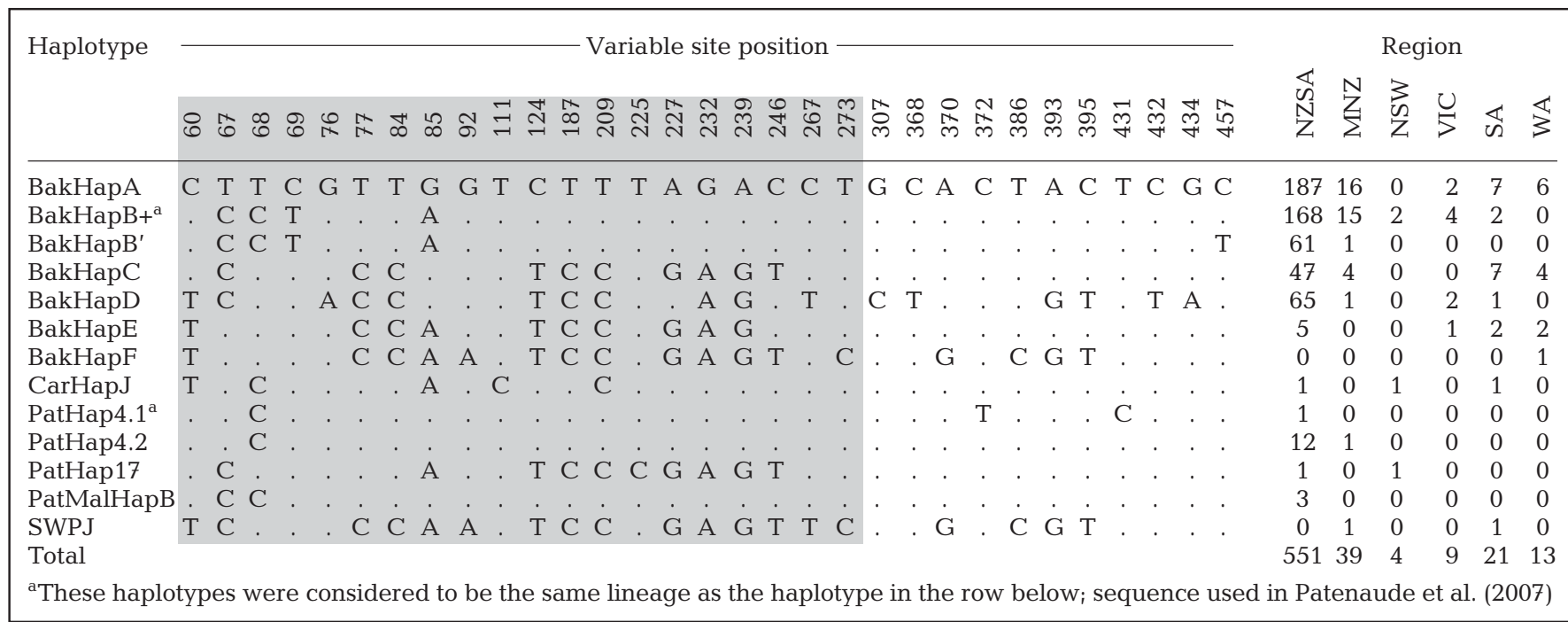


Table 3. Eubalaena australis. Diversity of mtDNA control region of southern right whale calving grounds and one migratory corridor from New Zealand (NZ) and Australia compared with other southern right whale populations (Patenaude et al. 2007) and the North Atlantic right whale Eubalaena glacialis (Malik et al. 2000, Rosenbaum et al. 2000) and bowhead whale Balaena mysticetus (Rooney et al. 2001), including the sample size (N), number of mitochondrial control region haplotypes ( $\mathrm{N}_{\mathrm{h}}$ ) and nucleotide $(\pi)$ and haplotype $(h)$ diversity. NZ subantarctic (NZSA) and mainland NZ (MNZ) were pooled for NZ, New South Wales (NSW) and Victoria (VIC) were pooled for southeast Australia (SEA), and South Australia (SA, migratory corridor) and Western Australia (WA) were pooled for southwest Australia (SWA)

\begin{tabular}{|c|c|c|c|c|c|c|c|c|c|c|}
\hline $\begin{array}{l}\text { Region or } \\
\text { population }\end{array}$ & $\mathrm{N}$ & $\begin{array}{l}\text { Length } \\
\text { (bp) }\end{array}$ & $\begin{aligned} & h \\
\pm & \mathrm{SD}\end{aligned}$ & $\begin{array}{l}\pi(\%) \\
\pm \mathrm{SD}\end{array}$ & $\mathrm{N}_{\mathrm{h}}$ & $\begin{array}{l}\text { Length } \\
\text { (bp) }\end{array}$ & $\begin{aligned} & h \\
\pm & \mathrm{SD}\end{aligned}$ & $\begin{array}{l}\pi(\%) \\
\pm \mathrm{SD}\end{array}$ & $\mathrm{N}_{\mathrm{h}}$ & Source \\
\hline \multicolumn{11}{|c|}{ Southern right whale } \\
\hline NZSA & 551 & 275 & $0.69 \pm 0.01$ & $1.93 \pm 1.03$ & 9 & 500 & $0.76 \pm 0.01$ & $1.50 \pm 0.07$ & 11 & Present study \\
\hline MNZ & 39 & 275 & $0.67 \pm 0.05$ & $1.71 \pm 0.95$ & 6 & 500 & $0.69 \pm 0.05$ & $1.16 \pm 0.06$ & 7 & Present study \\
\hline NZ (total) & 585 & 275 & $0.69 \pm 0.01$ & $1.91 \pm 1.02$ & 10 & 500 & $0.75 \pm 0.01$ & $1.43 \pm 0.74$ & 12 & Present study \\
\hline NSW & 4 & 275 & $0.83 \pm 0.22$ & $2.48 \pm 1.77$ & 3 & 500 & $0.83 \pm 0.22$ & $1.63 \pm 1.15$ & 3 & Present study \\
\hline VIC & 9 & 275 & $0.78 \pm 0.11$ & $2.61 \pm 1.53$ & 4 & 500 & $0.78 \pm 0.11$ & $2.07 \pm 1.19$ & 4 & Present study \\
\hline SEA (total) & 13 & 275 & $0.78 \pm 0.11$ & $2.51 \pm 1.42$ & 6 & 500 & $0.78 \pm 0.11$ & $1.90 \pm 0.10$ & 6 & Present study \\
\hline SA & 21 & 275 & $0.79 \pm 0.06$ & $2.55 \pm 1.39$ & 7 & 500 & $0.79 \pm 0.06$ & $1.66 \pm 0.09$ & 7 & Present study \\
\hline WA & 13 & 275 & $0.72 \pm 0.09$ & $2.31 \pm 1.32$ & 4 & 500 & $0.72 \pm 0.09$ & $1.43 \pm 0.08$ & 4 & Present study \\
\hline SWA (total) & 34 & 275 & $0.75 \pm 0.05$ & $2.40 \pm 1.29$ & 8 & 500 & $0.75 \pm 0.05$ & $1.50 \pm 0.82$ & 8 & Present study \\
\hline Argentina & 20 & 275 & $0.95 \pm 0.03$ & $2.82 \pm 1.53$ & 13 & & & & & Patenaude et al. (2007) \\
\hline South Africa & 41 & 275 & $0.94 \pm 0.02$ & $2.43 \pm 1.30$ & 21 & & & & & Patenaude et al. (2007) \\
\hline \multicolumn{11}{|c|}{ North Atlantic right whale } \\
\hline $\begin{array}{l}\text { Western North } \\
\text { Atlantic }\end{array}$ & 269 & 275 & $0.69 \pm 0.02$ & $0.60 \pm 0.30$ & 5 & & & & & $\begin{array}{l}\text { Rosenbaum et al. (2000), } \\
\text { Malik et al. (1999) }\end{array}$ \\
\hline \multicolumn{11}{|l|}{ Bowhead whale } \\
\hline $\begin{array}{l}\text { Bering-Chukchi } \\
\text {-Beaufort Seas }\end{array}$ & 98 & 453 & $0.99 \pm 0.01$ & $1.63 \pm 0.09$ & 68 & & & & & Rooney et al. (2001) \\
\hline
\end{tabular}

Table 4. Eubalaena australis. Genetic differentiation of southern right whale calving grounds and migratory corridor of New Zealand (NZ) and Australia. For testing of putative stocks, regions were pooled as follows: NZ subantarctic (NZSA) and mainland NZ (MNZ) were pooled for NZ; New South Wales (NSW) and Victoria (VIC) were pooled for southeast Australia (SEA); South Australia (SA; migratory corridor) and Western Australia (WA) were pooled for southwest Australia (SWA). (A) Pairwise mtDNA control region haplotype $F_{\mathrm{ST}}$ (top left quadrant) and $\Phi_{\mathrm{ST}}$ (top right quadrant) with sample size N. (B) Pairwise $F_{\mathrm{ST}}$ (bottom left quadrant) and $G_{\text {ST }}^{\prime}$ (bottom right quadrant) calculated from microsatellite allele frequencies based on an average sample size of $2 \mathrm{~N}$ per locus. NSW was omitted owing to the small sample size $(\mathrm{n}=4) .{ }^{*} \mathrm{p}<0.05 ;{ }^{* *}$ significance after sequential Bonferroni correction

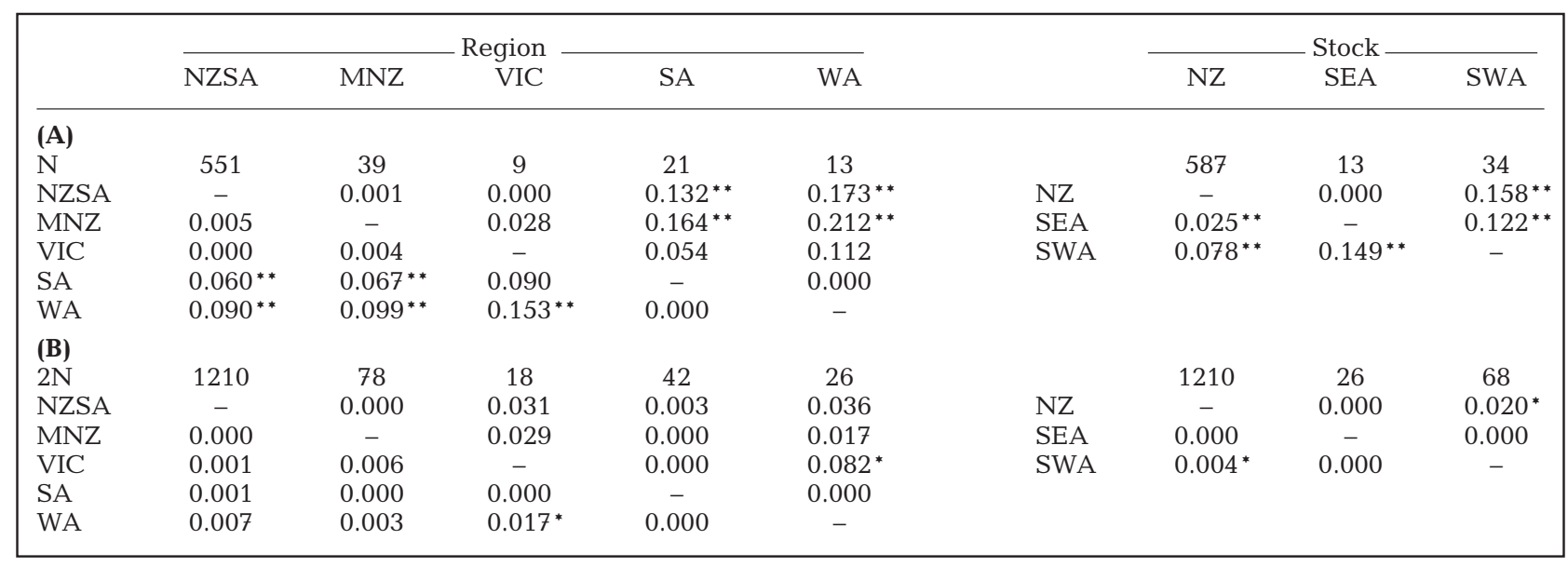

uals were admixed and assignment values were close to 0.5 . This indicates the program is assigning individuals randomly to $\mathrm{K}$ populations owing to the lack of underlying population structure (Latch et al. 2006, Martien et al. 2007, 2008).
Analysis of genotypes in FSTAT also failed to detect significant sex-biased dispersal between NZ and SWA (SEA sample was all females and was not included in the test). Neither sex-specific $F_{\mathrm{ST}}$ nor vAIC values were significantly different between males and females (Table 6). 


\section{DISCUSSION}

\section{Maternal philopatry and sex-biased gene flow}

Our comparison of mtDNA haplotype frequencies showed significant structuring of maternal lineages on southern right whale calving grounds across NZ and

Table 5. Eubalaena australis. Microsatellite diversity of southern right whales sampled on calving grounds and one migratory corridor of New Zealand (NZ) and Australia (13 loci) Mainland NZ (MNZ) and NZ subantarctic (NZSA) were pooled for NZ, New South Wales and Victoria (VIC) were pooled to form southeast Australia (SEA), and South Australia (SA) and Western Australia (WA) were pooled for southwest Australia (SWA). 2N: average sample size per loci; $k$ : mean number of alleles; AR: allelic richness; $H_{0}$ : observed heterozygosity; $H_{\mathrm{e}}$ : expected heterozygosity. NSW was omitted owing to the small sample size $(2 \mathrm{~N}=8)$

\begin{tabular}{|lrrccc|}
\hline Region & $2 \mathrm{~N}$ & \multicolumn{1}{c}{$k$} & $\mathrm{AR}$ & $H_{\mathrm{o}}$ & $H_{\mathrm{e}}$ \\
\hline NZSA & 1046 & 12.15 & 6.76 & 0.79 & 0.81 \\
MNZ & 70 & 9.15 & 6.71 & 0.79 & 0.80 \\
VIC & 18 & 6.31 & 6.31 & 0.83 & 0.82 \\
SA & 38 & 8.15 & 6.93 & 0.79 & 0.82 \\
WA & 24 & 6.77 & 6.18 & 0.80 & 0.80 \\
\hline \hline Stock & $2 \mathrm{~N}$ & \multirow{2}{*}{$k$} & $\mathrm{AR}$ & $H_{\mathrm{o}}$ & $H_{\mathrm{e}}$ \\
\hline SEA & 26 & 7.31 & 6.85 & 0.83 & 0.83 \\
SWA & 62 & 8.90 & 6.74 & 0.79 & 0.80 \\
NZ & 1108 & 12.07 & 6.76 & 0.79 & 0.81 \\
\hline
\end{tabular}
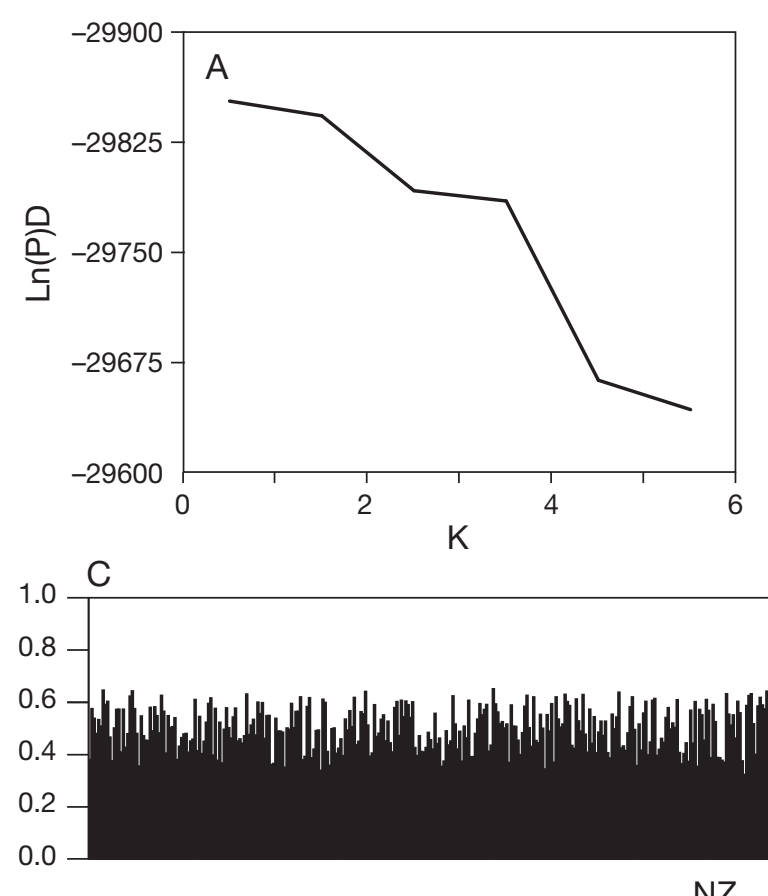

Fig. 2. Eubalaena australis. Inference of southern right whale population structure based on microsatellite allele frequencies

Australia. This confirms previous work (Baker et al. 1999, Patenaude et al. 2007) and extends it to a larger geographic range. In contrast to differentiation of mtDNA, we found only weak differentiation in allele frequencies of 13 microsatellite loci, with only the SWA and NZ comparison showing statistical significance. This weak difference was not reflected in the results of the STRUCTURE analysis, which is not surprising as the program does not generally detect weak population structure $\left(F_{\mathrm{ST}}<0.02\right.$; Latch et al. 2006). Although we believe this may be preliminary evidence for a difference in microsatellite allele frequencies between the 2 stocks, further work needs to be conducted with an increased SWA sample size in future.

The observed pattern of strong mtDNA structuring with limited differentiation in microsatellite loci is consistent with the expectation of female philopatry and male

Table 6. Eubalaena australis. Sex-biased dispersal test results based 13 microsatellite loci of southern right whales sampled from New Zealand (NZ) and southwest Australia (SWA). Differences in sex-specific $F_{\mathrm{ST}}$ values and variance of corrected assignment index (vAIc) were tested for significance using 10000 permutations.

\begin{tabular}{|llr|}
\hline & $F_{\text {ST }}$ & vAIc \\
\hline Males & 0.005 & 15.19 \\
Females & 0.003 & 13.59 \\
p-value & 0.75 & 0.32 \\
\hline
\end{tabular}

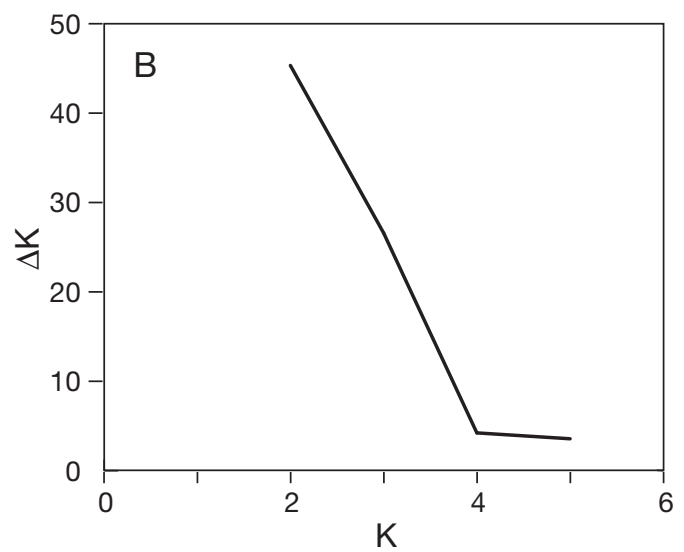
(13 loci) and using program STRUCTURE. (A) Mean log likelihood averaged over 6 iterations for $K=1$ to 6 . (B) Second order rate of change constant $(\Delta \mathrm{K})$ for $\mathrm{K}=1$ to 6 . (C) An example of the percentage of assignment of each individual to each population when $\mathrm{K}=2$; see Fig. 1 for definition of location abbreviations 
dispersal, a common life history pattern seen in mammals (Greenwood 1980), including other cetaceans (Baker et al. 1998, Pimper et al. 2010). Although our tests of sex-biased dispersal were not significant, this does not rule out sex-biased gene flow at some point during seasonal migration. It is unclear where and when mating occurs between southern right whales from different calving grounds or stocks, so it is difficult to put these results in context. As the southern right whale calves during the austral winter, and the estimated gestation period for southern right whales is from 10 to 13 mo (Lockyer 1984, Best 1994), it seems most likely that mating would also occur during this season. Indeed, mating behaviour is seen in several calving grounds (e.g. NZSA; Patenaude et al. 1998) in the form of surface-active groups (SAGs), where a focus animal is the subject of courtship displays (Payne 1986, Best et al. 2003). However, behavioural studies in South Africa and Argentina have shown much of this behaviour focuses on primiparous or juvenile females and only a small number of females are seen on the calving grounds the year before they calve (Payne 1986, Best et al. 2003). These findings indicate mating may be occurring outside of the calving grounds, perhaps during mixing on feeding grounds or by the undetected movement of whales between calving grounds.

The potential for mating between members of different stocks on feeding grounds is indicated by the apparent mixing of maternal lineages from distinct calving grounds, on feeding grounds in both the South Atlantic and South Pacific oceans (Baker et al. 1999, Patenaude et al. 2007). However, social and courtship behaviours are seen less frequently in high latitude feeding grounds (south of $40^{\circ} \mathrm{S}$ ) compared with winter calving grounds (Best et al. 2003), and the gestation period would have to be different from the expected 10 to 13 mo if mating was occurring on summer feeding grounds.

An alternate hypothesis, that the NZ and Australian populations diverged too recently for significant microsatellite differentiation to occur, is also possible. However, there are some examples of movement of individuals between putative stocks (e.g. NZSA to SA; Pirzl et al. 2009), which implies there is ongoing gene flow rather than recent divergence. Testing for paternity may help differentiate between the proximate and evolutionary hypotheses for the weak differentiation in nuclear markers.

\section{Maternal lineages and population structure}

One current New Zealand stock

The relationship between the $2 \mathrm{NZ}$ calving grounds, NZSA and MNZ, has been the subject of some speculation since the era of 19th century whaling. Results presented here indicate that right whales visiting these 2 areas show no significant differentiation in either mtDNA haplotype or microsatellite allele frequencies. In addition, we have shown the first direct matches between the 2 areas based on microsatellite genotype matching ( 5 females and 2 males). We believe this is sufficient evidence for these 2 areas to be considered a single NZ stock. Further evidence of the link between the 2 areas comes from recent satellite tagging work; one tagged whale moved from the NZSA to the South Island of New Zealand during the austral winter of 2009 (Childerhouse et al. 2010).

While there is good evidence to indicate these 2 areas currently represent a single stock, it is equivocal whether this was true throughout recent history. Given the low numbers and disappearance along the mainland coast compared with the NZSA, it is possible the species was extirpated from MNZ. If so, the links we see between the 2 areas today could be the result of recolonisation from NZSA to MNZ rather than the remnants of a single stock. Analyses of historical samples from both NZ calving grounds would be needed to comprehensively investigate this hypothesis and determine whether the 2 grounds were genetically or demographically isolated before whaling.

\section{Two Australian stocks}

The WA and SA sites appear to represent a single SWA stock based on the absence of difference in mtDNA haplotype and microsatellite allele frequency data. It is interesting that the sample from the SA migratory corridor sample is genetically closer to the WA calving ground than the VIC calving ground, despite being approximately 3 times farther away. This is consistent with the proposed large-scale migration pattern (counter-clockwise pattern). We also consider it likely that VIC and NSW form a single SEA stock based on available photo-identification data (Burnell 2001) and lack of genetic differentiation.

The comparison of the SEA and SWA stocks showed the highest degree of genetic differentiation based on mtDNA data (Table 4). Although the confidence in the genetic distinctiveness of the SEA calving ground is limited by the small sample size, this is inevitable in a remnant population. However, our proposal for 2 stocks is also supported by stark differences in recovery between SWA and SEA (Kemper et al. 1997, Bannister 2008, Burnell 2008) and is consistent with the majority of photo-identification studies, which have not documented movements between VIC or NSW and WA (Kemper et al. 1997, Burnell 2001, Pirzl et al. 2009).

As additional samples become available, isolation by distance along the coast and potential for complex 
migratory structure should be investigated. Tasmania would be a good site to include in future studies, as the number of sightings has increased since the $1980 \mathrm{~s}$; 70 individuals were sighted between 1993 and 2008 (Anonymous 2009). Such analyses will require a much larger and more systematic collection of samples than those currently available.

\section{‘Migratory memory' and units of conservation}

Fidelity to calving grounds can be viewed as a type of cultural memory, and it seems the memory of the suitable calving ground can be lost along with the whales that formerly inhabited such areas (Clapham et al. 2008). A loss of this cultural memory is thought to be a contributing factor to the absence of recovery in some southern right whale (e.g. Chile-Peru subpopulation; Reilly et al. 2008) and humpback whale Megaptera novaeangliae calving grounds (e.g. Fiji $i_{\text {, Gibbs et }}$ al. 2006). While southern right whales exhibit some plasticity in their philopatric behaviour (e.g. Best et al. 1993, Rowntree et al. 2001), it appears rare and it is unlikely that such novel behaviour will enable calving grounds to recover in a time frame relevant to management. Clapham et al. (2008, p. 195) argue that management units for whales should 'be based upon any unit that, if extirpated, would not recover by any mechanism within a management [decadal] time frame'. Given the historical pattern of depletion and the current differentiation of mtDNA and microsatellite loci, there is strong evidence to consider NZ and SWA as distinct management units. Furthermore, we believe the results presented here should be considered preliminary evidence of a distinct SEA stock. We urge this precautionary approach owing to the small size of the SEA stock and encourage further investigation of stock identity and anthropogenic impacts on the southeast Australian southern right whale calving ground.

Acknowledgements. Samples were collected under New Zealand Department of Conservation (DOC) Marine Mammal Research permit and University of Auckland Animal Ethics Committee approved protocol (to C.S.B.) in the Auckland Islands. Biopsy sampling in Western Australia was undertaken under permit from the Western Australian Department of Conservation and Land Management, with approval from the Animal Ethics Committee, Murdoch University. Samples in South Australia, Victoria and New South Wales were collected under the Environment Protection and Biodiversity Conservation Act 1999 Cetacean permits E2002/ 0035, 20080001; Macquarie University Animal Ethics Committee 2001/ 007, 2002/015 and 2007/013; SA Department of Environment and Heritage (DEH SA) Scientific Permit W24463; SA Wildlife Ethics Committee 13/2001; Natural Resources and Environment Vic research permits 10001108, 10002043, 10002922 and 10004512; and NSW Scientific Licence A3023 and S10766. The 1995 to 1998 Auckland Islands field trips were funded by the Whale and Dolphin Conservation Society, the US Department of State (Program for Cooperative US/New Zealand Antarctic Research), the Auckland University Research Council and the New Zealand Marsden Fund. The 2006 to 2008 New Zealand subantarctic field trips were funded by Blue Planet Marine, Brian Skerry Photography, Holsworth Wildlife Research endowment, the Marine Conservation Action Fund, National Geographic, the Winifred Violet Scott Estate Research Grant Fund and DOC. Logistic support was given by the Southland DOC Conservancy, University of Auckland and the Australian Antarctic Division. Thanks are extended to Glenn Dunshea, and the captains and crews of the 'Maia' and the 'Evohe' for their help and support in the field. Field work and sample collection in Australia was supported by the Scott Foundation (estate of the late W. V. Scott), the Western Australian Museum, Environment Australia, the Australian Marine Mammal Centre, Department of Environment, Heritage and the Arts, M. Watson, I. Westhorpe and staff of the Department of Sustainability and Environment Victoria and Pirvic, C. Halstead and staff of DEH SA, K. Bilgmann, students from the Marine Mammal Research Group at Macquarie University and staff of the Department of Environment, Climate Change and Water NSW. We thank Rob Suisted, formerly of DOC, for initiating the study of right whales around the NZ mainland. Around the New Zealand mainland, sample collection was made possible by D. Engelhaupt and DOC staff, including R. Cole, J. Fyfe, P. McClelland, P. Brady, H. Kettles, J. Quirk, D. Neale, B. Williams, M. Morrissey and M. Ogle. Laboratory work was funded by the Marsden Fund of New Zealand, DOC, the Heseltine Trust and an OMV New Zealand Ltd. Scholarship (to E.C.). We thank P. Tsai and R. Fewster for help with population structure analyses. E.C. was supported by a Tertiary Education Commission Top Achiever Scholarship.

\section{LITERATURE CITED}

Aasen E, Medrano J (1990) Amplification of the $Z F X$ and $Z F Y$ genes for sex identification in humans, cattle, sheep and goats. Nat Biotechnol 8:1279-1281

Anonymous (2009) Report of the Australian southern right whale workshop, 19-20 March 2009. Australian Antarctic Division, Kingston

Baker CS, Slade RW, Bannister JL, Abernethy R and others (1994) Hierarchical structure of mitochondrial DNA gene flow among humpback whales, Megaptera novaeangliae, world-wide. Mol Ecol 3:313-327

> Baker CS, Medrano-Gonzalez L, Calambokidis J, Perry A and others (1998) Population structure of nuclear and mitochondrial DNA variation among humpback whales in the North Pacific. Mol Ecol 7:695-707

Baker CS, Patenaude NJ, Bannister JL, Robins J, Kato H (1999) Distribution and diversity of mtDNA lineages among southern right whales (Eubalaena australis) from Australia and New Zealand. Mar Biol 134:1-7

Bannister JL (1986) Notes on nineteenth century catches of southern right whales (Eubalaena australis) off the southern coasts of Western Australia. Rep Int Whal Comm Spec Issue 10:255-259

Bannister JL (2008) Population trend in right whales off southern Australia 1993-2007. Unpublished report (SC/60/ BRG14) presented to the Scientific Committee of the International Whaling Commission, Cambridge. Available on request from secretariat@iwcoffice.org

Bannister JL (2009) Southern right whale aerial survey, southern Australian coast, 2009. Final report on work funded by the Island Foundation. Island Foundation, Marion, MA 
Bannister JL, Pastene A, Burnell SR (1999) First record of a southern right whale (Eubalaena australis) between warm water breeding grounds and the Antarctic Ocean, south of $60^{\circ}$ S. Mar Mamm Sci 15:1337-1342

Bérubé M, Jørgensen H, McEwing R, Palsbøll P (2000) Polymorphic di-nucleotide microsatellite loci isolated from the humpback whale Megaptera novaeangliae. Mol Ecol 9: $2181-2183$

Best P (1994) Seasonality of reproduction and the length of gestation in southern right whales Eubalaena australis. J Zool 232:175-189

Best P, Payne R, Rowntree V, Palazzo J, Do Carmo Both M (1993) Long-range movements of South Atlantic right whales, Eubalaena australis. Mar Mamm Sci 9:227-234

Best P, Brandao A, Butterworth D (2001) Demographic parameters of southern right whales off South Africa. J Cetacean Res Manag 2(Spec Issue):161-169

Best P, Schaeff C, Reeb D, Palsbøll P (2003) Composition and possible function of social groupings of southern right whales in South African waters. Behaviour 140:1469-1494

Best P, Brandao A, Butterworth D (2005) Updated estimates of demographic parameters for southern right whales off South Africa. Unpublished report (SC/57/BRG2) presented to the Scientific Committee of the International Whaling Commission, Cambridge. Available from http:// iwcoffice.org/_documents/sci_com/workshops/MSYR/SC57-BRG2.pdf

Bonin A, Bellemain E, Eidesen PB, Pompanon F, Brochmann C, Taberlet P (2004) How to track and assess genotyping errors in population genetic studies. Mol Ecol 13: 3261-3273

Burnell SR (2001) Aspects of the reproductive biology, movements and site fidelity of right whales off Australia. J Cetacean Res Manag 2(Spec Issue):89-102

Burnell SR (2008) Estimates of demographic parameters of southern right whales off Australia. Unpublished report (SC/60/BRG12) presented to the Scientific Committee of the International Whaling Commission, Cambridge. Available on request from secretariat@iwcoffice.org

Childerhouse S, Double M, Gales N (2010) Satellite tracking of southern right whales (Eubalaena australis) at the Auckland Islands, New Zealand. Unpublished report (SC/62/BRG19) presented to the Scientific Committee of the International Whaling Commission, Cambridge. Available from http://iwcoffice.org/_documents/sci_com/SC62 docs/SC-62-BRG19.pdf

> Clapham P, Aguilar A, Hatch LT (2008) Determining spatial and temporal scales for management of cetaceans: lessons from whaling. Mar Mamm Sci 24:183-201

Cooke J, Rowntree V, Payne R (2001) Estimates of demographic parameters for southern right whales (Eubalaena australis) observed off Peninsula Valdes, Argentina. J Cetacean Res Manag 2(Spec Issue):125-132

Dawbin W (1986) Right whales caught in waters around south eastern Australia and New Zealand during the nineteenth and early twentieth centuries. Rep Int Whal Comm Spec Issue 10:261-268

Drummond AJ, Kearse M, Heled J, Moir R and others (2006) Geneious v. 2.5. Available at www.geneious.com

- Evanno G, Regnaut S, Goudet J (2005) Detecting the number of clusters of individuals using the software STRUCTURE: a simulation study. Mol Ecol 14:2611-2620

> Excoffier L, Laval G, Schneider C (2005) Arlequin (version 3.0): an integrated software package for population genetics data analysis. Evol Bioinform Online 1:47-50

> Frasier TR, Rastogi T, Brown MW, Hamilton P, Kraus SD, White BN (2006) Characterization of tetranucleotide microsatellite loci and development and validation of mul- tiplex reactions for the study of right whale species (genus Eubalaena). Mol Ecol Notes 6:1025-1029

Gaskin DE (1964) Return of the southern right whale (Eubalaena australis Desm.) to New Zealand waters, 1963. Tuatara 12:115-118

Gibbs N, Paton D, Childerhouse S, Clapham P (2006) Assessment of the current abundance of humpback whales in the Lomaiviti Island Group of Fiji and a comparison with historical data. Unpublished report (SC/A06/HW34) presented to the International Whaling Commission Comprehensive Assessment of Southern Hemisphere Humpback Whales 2006, Hobart. Available on request from secretariat@iwcoffice.org

Gilson A, Syvanen M, Levine K, Banks J (1998) Deer gender determination by polymerase chain reaction: validation study and application to tissues, bloodstains, and hair forensic samples from California. Calif Fish Game 84: 159-169

Goudet J (2001) FSTAT, a program to estimate and test gene diversities and fixation indices (version 2.9). Available at www.unil.ch/izea/softwares/fstat.html

Goudet J, Perrin N, Waser PM (2002) Tests for sex-biased dispersal using bi-parentally inherited genetic markers. Mol Ecol 11:1103-1114

Greenwood P (1980) Mating systems, philopatry and dispersal in birds and mammals. Anim Behav 28:1140-1162

Hedrick PW (2005) A standardized genetic differentiation measure. Evolution 59:1633-1638

Holm S (1979) A simple sequentially rejective multiple test procedure. Scand J Stat 6:65-70

IWC (International Whaling Commission) (1986) Right whales: past and present status: proceedings of the workshop on the status of right whales. Rep Int Whal Comm 44:146-152

IWC (International Whaling Commission) (2001) Report of the workshop on the comprehensive assessment of right whales: a worldwide comparison. J Cetacean Res Manag 2(Spec Issue): $1-60$

Kalinowski S, Taper M, Marshall T (2007) Revising how the computer program CERVUS accommodates genotyping error increases success in paternity assignment. Mol Ecol 9:801-888

Kemper CM, Mole J, Warnecke RM, Ling JK, Needham PN, Wapstra JE (1997) Southern right whales in south-eastern Australia - aerial surveys in 1991-1993 and incidental information from 1904. In: Hindell M, Kemper C (eds) Marine mammal research in the Southern Hemisphere: status, ecology and medicine. Surrey Beatty and Sons, Chipping Norton, p 40-55

Krützen M, Barré L, Möller L, Heithaus M, Simmer C, Sherwin WB (2002) A biopsy system for small cetaceans; darting success and wound healing in Tursiops spp. Mar Mamm Sci 18:863-878

Lambertsen R (1987) A biopsy system for large whales and its use for cytogenetics. J Mammal 68:443-445

Latch E, Dharmarajan G, Glaubitz J, Rhodes O (2006) Relative performance of Bayesian clustering software for inferring population substructure and individual assignment at low levels of population differentiation. Conserv Genet 7: 295-302

Lockyer C (1984) Review of baleen whale (Mysticeti) reproduction and implications for management. Rep Int Whal Comm Spec Issue 6:27-50

Malik S, Brown M, Kraus S, White B (2000) Analysis of mitochondrial DNA diversity within and between North and South Atlantic right whales. Mar Mamm Sci 16: $545-558$

Martien K, Archie EA, Taylor BL (2007) Simulation-based 
performance testing of the Bayesian clustering program STRUCTURE. Unpublished report (SC/59/SD3) presented to the Scientific Committee of the International Whaling Commission, Cambridge. Available at http://swfsc.noaa gov/uploadedFiles/Divisions/PRD/Programs/Population Identity/TOSSM/SC-59-SD3_structure_performance.pdf

Martien K, Givens GH, Archer E (2008) A note on the ability of STRUCTURE to correctly infer the number of populations for Bering-Chukchi-Beaufort seas bowhead whales. Unpublished report (SC/59/BRG34) presented to the Scientific Committee of the International Whaling Commission, Cambridge. Available at http://iwcoffice.org/ _documents/sci_com/SC59docs/SC-59-BRG34.pdf

McKelvey KS, Schwartz MK (2005) DROPOUT: a program to identify problem loci and samples for noninvasive genetic samples in a capture-mark-recapture framework. Mol Ecol Notes 5:716-718

- Meirmans PG (2006) Using the AMOVA framework to estimate a standardized genetic differentiation measure. Evolution 60:2399-2402

> Meirmans P, van Tienderen P (2004) GENOTYPE and GENODIVE: two programs for the analysis of genetic diversity of asexual organisms. Mol Ecol Notes 4:792-794

> Narum S (2006) Beyond Bonferroni: less conservative analyses for conservation genetics. Conserv Genet 7:783-787

> Oremus M, Poole M. Steel D, Baker CS (2007) Isolation and interchange among insular spinner dolphin communities in the South Pacific revealed by individual identification and genetic diversity. Mar Ecol Prog Ser 336:275-289

$>$ Paetkau D, Strobeck C (1994) Microsatellite analysis of genetic variation in black bear populations. Mol Ecol 3: 489-495

Palsbøll PJ, Bérubé M, Larsen AH, Jørgensen H (1997) Primers for the amplification of tri- and tetramer microsatellite loci in baleen whales. Mol Ecol 6:893-895

Patenaude NJ (2002) Demographic and genetic status of right whales at the Auckland Islands, New Zealand. PhD thesis, University of Auckland

Patenaude NJ (2003) Sightings of southern right whales around 'mainland' New Zealand. Science for Conservation, Vol 225. New Zealand Department of Conservation, Wellington. Available at www.doc.govt.nz/upload/ documents/science-and-technical/sfc225a.pdf

> Patenaude NJ, Baker CS, Gales N (1998) Observations of southern right whales on New Zealand's subantarctic wintering grounds. Mar Mamm Sci 14:350-355

$>$ Patenaude NJ, Portway V, Schaeff C, Bannister JL and others (2007) Mitochondrial DNA diversity and population structure among southern right whales (Eubalaena australis). J Hered 98:147-157

Payne R (1986) Long term behavioural studies of southern right whale (Eubalaena australis). Rep Int Whal Comm Spec Issue 10:161-168

> Peakall R, Smouse P (2006) GENALEX 6: genetic analysis in excel. Population genetic software for teaching and research. Mol Ecol Notes 6:288-295

> Pimper LE, Baker CS, Goodall RNP, Olavarria C, Remis MI (2010) Mitochondrial DNA variation and population structure of Commerson's dolphins (Cephanlorynchus commersonii) in their southernmost distribution. Conserv Genet 11: 2157-2168

Pirzl R, Patenaude NJ, Burnell SR, Bannister JL (2009) Move-

Editorial responsibility: Philippe Borsa,

Montpellier, France ments of southern right whales (Eubalaena australis) between Australia and subantarctic New Zealand populations. Mar Mamm Sci 25:455-461

Pompanon F, Bonin A, Bellemain E, Taberlet P (2005) Genotyping errors: causes, consequences and solutions. Nat Rev Genet 6:847-859

Pritchard JK, Stephens M, Donnelly P (2000) Inference of population structure using multilocus genotype data. Genetics 155:945-959

Raymond M, Rousset F (1995) An exact test for population differentiation. Evolution 49:1280-1283

Reilly SB, Bannister JL, Best P, Brown MW and others (2008) Eubalaena australis (Chile-Peru subpopulation). In: International Union for Conservation of Nature and Natural Resources (IUCN) 2009. IUCN red list of threatened species, version 2009.2. Available at www.iucn.redlist.org

Rice W (1989) Analyzing tables of statistical tests. Evolution 43:223-225

Richards R (2002) Southern right whales: a reassessment of their former distribution and migration routes in New Zealand waters, including the Kermadec grounds. J R Soc NZ 32:355-377

Rousset F (2008) GENEPOP'007: a complete re-implementation of the GENEPOP software for Windows and Linux. Mol Ecol Resour 8:103-106

Rooney A, Honeycutt R, Derr J (2001) Historical population size change of bowhead whales inferred from DNA sequence polymorphism data. Evolution 55:1678-1685

Rosenbaum H, Brown M, Schaeff C, Portway V and others (2000) Worldwide differentiation of Eubalaena: questioning the number of right whale species. Mol Ecol 9: 1793-1802

Rowntree V, Payne R, Schell D (2001) Changing patterns of habitat use by southern right whales (Eubalaena australis) on their nursery ground at Peninsula Valdes, Argentina, and in their long-range movements. J Cetacean Res Manag 2(Spec Issue):133-143

Sambrook J, Fritsch EF, Maniatis T (1989) Molecular cloning: a laboratory manual, 2nd edn. Cold Spring Harbor Laboratory Press, Cold Spring Harbor, NY

Sherrin R (1886) Handbook of the fishes of New Zealand. Wilsons \& Horton, Auckland

Stewart S, Todd B (2001) A note on observations of southern right whales at Campbell Island, New Zealand. J Cetacean Res Manag 2(Spec Issue):117-120

Tormosov D, Mikhaliev Y, Best P, Zemsky V, Sekiguchi M, Brownell R (1998) Soviet catches of southern right whales Eubalaena australis 1951-1971: biological data and conservation implications. Biol Conserv 86:185-197

Valsecchi E, Amos W (1996) Microsatellite markers for the study of cetacean populations. Mol Ecol 5:151-156

van Oosterhout C, Hutchinson W, Wills D, Shipley P (2004) MICROCHECKER: software for identifying and correcting genotyping errors in microsatellite data. Mol Ecol 8: 1762-1765

- Waldick RC, Brown MW, White BN (1999) Characterization and isolation of microsatellite loci from the endangered North Atlantic right whale. Mol Ecol 8:1763-1765

Weir B, Cockerham C (1984) Estimating F-statistics for the analysis of population structure. Evolution 38:1358-1370

> Wright S (1949) The genetical structure of populations. Ann Eugen (= Ann Hum Gen) 15:323-354

Submitted: September 24, 2010; Accepted: March 24, 2011

Proofs received from author(s): June 13, 2011 